\title{
Antibacterial activity and mode of action of the Artemisia capillaris essential oil and its constituents against respiratory tract infection-causing pathogens
}

\author{
CHANG YANG ${ }^{1}$, DONG-HUI HU ${ }^{2}$ and YAN FENG ${ }^{3}$ \\ Departments of ${ }^{1}$ Respiratory and ${ }^{2}$ Liver Disease, Zhongshan Hospital; ${ }^{3}$ Department of Pathology, \\ First Hospital of Wuhan, Wuhan, Hubei 430033, P.R. China
}

Received February 4, 2014; Accepted September 19, 2014

DOI: $10.3892 / \mathrm{mmr} .2014 .3103$

\begin{abstract}
Inhalation therapy using essential oils has been used to treat acute and chronic sinusitis and bronchitis. The aim of the present study was to determine the chemical composition of the essential oil of Artemisia capillaris, and evaluate the antibacterial effects of the essential oil and its main components, against common clinically relevant respiratory bacterial pathogens. Gas chromatography and gas chromatography-mass spectrometry revealed the presence of 25 chemical constituents, the main constituents being: $\alpha$-pinene, $\beta$-pinene, limonene, 1,8 -cineole, piperitone, $\beta$-caryophyllene and capillin. The antibacterial activities of the essential oil, and its major constituents, were evaluated against Streptococcus pyogenes, methicillin-resistant Staphylococcus aureus (MRSA), MRSA (clinical strain), methicillin-gentamicin resistant Staphylococcus aureus (MGRSA), Streptococcus pneumoniae, Klebsiella pneumoniae, Haemophilus influenzae and Escherichia coli. The essential oil and its constituents exhibited a broad spectrum and variable degree of antibacterial activity against the various strains. The essential oil was observed to be much more potent, as compared with any of its major chemical constituents, exhibiting low minimum inhibitory and bacteriocidal concentration values against all of the bacterial strains. The essential oil was most active against $S$. pyogenes, MRSA (clinical strain), S. pneumoniae, K. pneumoniae, H. influenzae and $E$. coli. Piperitone and capillin were the most potent growth inhibitors, among the major chemical constituents. Furthermore, the essential oil of A. capillaris induced significant and dose-dependent morphological changes in the S. aureus bacterial strain, killing $>90 \%$ of the bacteria when
\end{abstract}

Correspondence to: Dr Yan Feng, Department of Pathology, First Hospital of Wuhan, 215 Zhongshan Road, Riverbank District, Wuhan, Hubei 430033, P.R. China

E-mail: fengyan197701@gmail.com

Key words: Artemisia capillaris, essential oil, Staphylococcus aureus, capillin administered at a higher dose; as determined by scanning electron microscopy. In addition, the essential oil induced a significant leakage of potassium and phosphate ions from the $S$. aureus bacterial cultures. These results indicate that the antibacterial action of $A$. capillaris essential oil may be mediated through the leakage of these two important ions. In conclusion, A. capillaris essential oil exhibits potent antibacterial activity by inducing morphological changes and leakage of ions in S. aureus bacterial cultures.

\section{Introduction}

Upper respiratory tract infection (URTI) are disorders caused by acute infections, usually affecting the nose, sinuses, pharynx, or larynx. The various URTIs include the common cold, sinusitis, laryngitis and pharyngitis, amongst others (1). URTIs are usually caused by viruses, such as rhinoviruses, coronaviruses, parainfluenza virus and adenoviruses (2). However, numerous URTIs are also caused by bacteria, including Streptococcus pyogenes, Streptococcus pneumoneae, Heamophilus influenzae, Corynebacterium diptheriae, Bordetella pertussis and Bacillus anthracis. Bronchitis, which is an inflammation of the mucous membranes of the bronchi, can also be caused by certain types of bacteria. Approximately $10 \%$ of bronchitis cases are caused by bacteria, such as Mycoplasma pneumoniae, Chlamydophila pneumoniae, $B$. pertussis and $S$. pneumoniae $(3,4)$.

Essential oils are composed of an odoriferous mixture of monoterpenes, sesquiterpenes and aromatic compounds, and form an important part of naturopathic therapy, where they are well-known for their antimicrobial properties. Essential oils were among the first topical and gastrointestinal antimicrobial agents used by mankind. Due to the recent, extensive use of conventional antibiotics and synthetic antimicrobial drugs, there has been an increase in the widespread development of drug resistant microorganisms, including methicillin-resistant Staphylococccus aureus (MRSA), and multidrug resistant strains of Klebsiella pneumoniae and Pseudomonas aeruginosa. These drug-resistant microbes pose a challenge for scientists to identify alternative ways to treat microbial infections. Essential oils are antimicrobial agents with multiple target sites. The essential oils and their components target 
the bacterial cell wall and cytoplasmic membrane, resulting in permeabilization, which is followed by the loss of ions, reduction of the membrane potential, collapse of the proton pump and depletion of the ATP pool (5-7). Due to their multifunctionality, essential oils have a potentially large application in medicine and aromatherapy. Essential oils have been shown to exhibit potent antimicrobial actions against a wide range of both Gram-positive and Gram-negative bacteria (8).

Essential oils have also been used traditionally for treating respiratory tract infections, and are currently used as alternative medicines for the treatment of colds (9-11). Inhalation therapy using essential oils, has previously been used to treat acute sinusitis, and acute and chronic bronchitis. It has been reported that inhalation therapy using volatile essential oil vapors, is capable of enhancing the respiratory tract fluid output (12), maintaining the ventilation and drainage of the sinuses, and reducing asthma and inflammation of the trachea (13-15).

The present study aimed to determine the chemical composition of the essential oil of Artemisia capillaris as well as to evaluate the antibacterial effects of Artemisia capillaris and its primary components against common clinically relevant respiratory bacterial pathogens. Gas chromatography mass spectrometry was used to study the chemical composition of the oil. In addition, Agar well diffusion assays and micro-well dilution methods were used to study the antibacterial susceptibility of the microbes towards the essential oil. Furthermore, Scanning Electron Microscopy (SEM) was used to study the morphological changes which occurred following oil exposure.

\section{Materials and methods}

Materials. The major essential oil components: $\alpha$-pinene, $\beta$-pinene, limonene, 1,8 - cineole, piperitone, $\beta$-caryophyllene and capillin were all purchased from Sigma-Aldrich (St Louis, MO, USA).

Plant material. The aerial portions of the Artemisia capillaris plant were collected from a local region in Jianguo, China, between June and July 2013. The plant was identified by an experienced taxonomist.

Essential oil isolation. The extraction of the essential oil from the aerial parts of A.capillaris, was carried out by hydrodistillation for $3 \mathrm{~h}$ using Clevenger-type apparatus (Lianyungang Hightborn Technology Co., Ltd, Jiangsu, China), as recommended in the European Pharmacopoeia (16). Three samples of the dried aerial parts $(200 \mathrm{~g})$ were subjected to hydrodistillation at separate times. The essential oil was collected, dehydrated with $\mathrm{Na}_{2} \mathrm{SO}_{4}$ (Sigma-Aldrich), and stored at $4^{\circ} \mathrm{C}$ until further use.

Essential oil analysis. The essential oil was analyzed by a combination of gas chromatography-flame ionization detection (GC-FID) and gas chromatography-mass spectrometry (GC-MS) analytical techniques.

GC-FID analysis. GC-FID was carried out using a Perkin Elmer AutoSystem XL Gas Chromatograph 8500 series (Perkin Elmer, Waltham, MA, USA), with a flame ionization detector and head space analyzer, using a fused silica capillary column HP-5 (30 m x $0.25 \mathrm{~mm} \times 0.25 \mu \mathrm{m}$ ) coated with dimethyl polysiloxane. The oven temperature was programmed from $50-260^{\circ} \mathrm{C}$ at $2^{\circ} \mathrm{C} / \mathrm{min}$, with an injector temperature of $250^{\circ} \mathrm{C}$ and a detector temperature of $260^{\circ} \mathrm{C}$. The injection volume was $0.8 \mu \mathrm{l}$, and nitrogen was used as the carrier gas $(1.2 \mathrm{ml} / \mathrm{min})$.

GC-MS analysis. GC-MS analysis was conducted using a Varian Gas Chromatograph series 3800 (Varian Medical Systems, Palo Alto, CA, USA) fitted with a VF-5 MS fused silica capillary column (60 m x $0.25 \mathrm{~mm}, \mathrm{x} 0.25 \mu \mathrm{m})$, using split/splitless injection, and coupled with a 4000 series mass detector. The GC-MS was conducted under the following conditions: injection volume $0.8 \mu \mathrm{l}$ with a split ratio of $1: 80$, helium was used as the carrier gas $(1.5 \mathrm{ml} / \mathrm{min}$ constant flow mode), an injector temperature of $250^{\circ} \mathrm{C}$, and the oven temperature was programmed from $50-260^{\circ} \mathrm{C}$ at $2^{\circ} \mathrm{C} / \mathrm{min}$. Mass spectra was produced with an electron impact (EI+) mode $70 \mathrm{ev}$, and ion source temperature $260^{\circ} \mathrm{C}$. The mass spectra were recorded at a range between 50-500 a.m.u.

Identification of components. Identification of the essential oil constituents was based on the Retention Index, which was determined with respect to a homologous series of n-alkanes (C5-C28; Polyscience, Niles, IL, USA), which underwent the same experimental conditions; co-injection with standards (Sigma Aldrich and standard isolates); an MS Library search (NIST 05 and Wiley); and by comparing the MS data of the present study with the previous MS literature data (17).

\section{Antibacterial testing}

Bacterial strains and culture media. S pyogenes [American Type Culture Collection (ATCC) 12344], MRSA (ATCC 43300), MRSA (clinical strain), Methicillin-gentamicin resistant S. aureus (MGRSA; ATCC 33592), S. pneumoniae (ATCC 2730), K. pneumoniae (ATCC 27853), H. influenzae (ATCC 33391), E. coli (clinical strain) were used in the present study. All of these bacterial strains were obtained from the State Key Laboratory of Microbial Resources, the Institute of Microbiology, Chinese Academy of Sciences (Beijing, China). The bacterial strains were grown on nutrient agar plates, at $37^{\circ} \mathrm{C}$, and maintained on nutrient agar slants. Cell suspensions of the micro-organisms in $0.5 \% \mathrm{NaCl}$, were adjusted at 0.5 Mcfarland to obtain $\sim 10^{6} \mathrm{cfu} / \mathrm{ml}$.

Agar well diffusion assay. The antibacterial susceptibility test was conducted using the agar well diffusion assay. The overnight bacterial cultures were added to $30 \mathrm{ml}$ of liquid nutrient agar. The contents of the tubes were then transferred to petri plates. Following 20 min solidification of the agar petri plates, at $25^{\circ} \mathrm{C}$, the wells of the plates were filled with $20 \mu \mathrm{l}$ neat A. capillaris essential oil and the major chemical constituents. The plates were then incubated for $24 \mathrm{~h}$ at $37^{\circ} \mathrm{C}$. Following the incubation, the antimicrobial efficacy of the essential oil and its individual constituents was determined by calculating the width of the inhibition zone. The inhibition zones were expressed in mm. All of the experiments were repeated in triplicate. Ampicillin and vancomycin, (10 $\mu \mathrm{g} / \mathrm{disc})$ were used as positive controls.

Determination of minimum inhibitory concentration (MIC) and minimum bactericidal concentration $(M B C)$ values. The MIC of the essential oil was determined using the micro-well 
dilution method, as recommended by the National Committee for Clinical Laboratory Standards, as reported by previous methods (18). The essential oil and its chemical constituents were dissolved in dimethylsulfoxide $(2 \mathrm{mg} / \mathrm{ml})$ and diluted to prepare concentrations in the range of $0.10-392.8 \mu \mathrm{g} / \mathrm{ml}(0.1$, $0.2,0.4,0.8,1.6,3.2,6.4,12.8,24.6,49.2,98.4,196$ and 392.8 $\mu \mathrm{g} / \mathrm{ml})$. The inoculum suspensions, with a final concentration of $0.5 \times 10^{6} \mathrm{cfu} / \mathrm{ml}$, were added to 96 -well microplates. A total of $150 \mu \mathrm{l}$ Mueller Hinton (MH) broth was added to the wells of the 10th column, which was reserved for the bacterial growth control. The wells of the 11th column were reserved for the control of broth sterility. The wells of the final column were used as a negative control, containing $150 \mu \mathrm{l}$ of nutrient broth and $5 \mu \mathrm{l}$ of inoculum. Following a $24 \mathrm{~h}$ incubation period at $37^{\circ} \mathrm{C}$, the plates were screened visually for broth turbidity. The MIC was defined as the lowest concentration of the essential oil and the components at which the bacteria did not exhibit any visible growth, following the $24 \mathrm{~h}$ incubation at $37^{\circ} \mathrm{C}$. The MBC was defined as the lowest concentration of the essential oil and the components at which $99.9 \%$ of the bacterial population were killed, following the $24 \mathrm{~h}$ incubation at $37^{\circ} \mathrm{C}$.

SEM. The essential oil-treated bacterial cells were obtained for SEM. Briefly, an overnight culture of S. aureus (clinical strain), grown on $\mathrm{MH}$ agar at $37^{\circ} \mathrm{C}$, was added to a saline solution containing $0.1 \%$ Tween ${ }^{\circledR}-80$ (Shanghai Sungo Technology and Trade Co., Ltd, Shanghai, China). Four different concentrations of the A. capillaris essential oil (20, 40, 60 and $80 \mu \mathrm{g} / \mathrm{ml}$ ) were prepared and added to the suspension, which was then incubated at room temperature. Following a $24 \mathrm{~h}$ incubation, the bacterial cells were centrifuged at $8000 \mathrm{x} g$ for $15 \mathrm{~min}$. The bacterial cells were then washed with $0.1 \mathrm{~mol} / \mathrm{l}$ Tris-acetate buffer ( $\mathrm{pH} 7.1)$, fixed in Tris-acetate buffer containing $1.5 \%$ glutaraldehyde, and freeze-dried. Each of the bacterial cultures was observed using a SEM (Shenzhen Jinliyang Technology Co., Ltd., Guangdong, China), at magnification 10,000x. A bacterial cell suspension in saline, with no essential oil treatment, was used as a positive control.

Determination of potassium and phosphate ion efflux. Overnight bacterial cultures of $S$. aureus were harvested and washed three times in deionized water. The bacterial cells were treated with $50 \mu \mathrm{l}$ A. Capillaris essential oil and the concentration of extracellular potassium and phosphate ions was estimated, using an ion selective electrode and a phosphorous inorganic kit 670-A (Sigma-Aldrich), respectively. The numerical values were compared with standard calibration curves of $\mathrm{HPO}_{4}$ and $\mathrm{KCl}$ for determination of phosphate and potassium ion efflux, respectively. To observe the dead and viable cells both prior to resuspension in water, and during the incubation period at $37^{\circ} \mathrm{C}$ in the absence of an antimicrobial agent, $70 \mu \mathrm{l}$ of the bacterial cultures were transferred to $250 \mu \mathrm{l}$ $\mathrm{MH}$ broth, and variations in optical density were recorded using a Bioscreen (Shanghai Vizai Trade and Development Co., Ltd, Shanghai, China).

\section{Results}

Chemical composition of the essential oil of A. capillaris. The yield of the essential oil obtained from the dry aerial parts of $A$. capillaris was $\sim 1.6 \% \mathrm{w} / \mathrm{v}$. The chemical components of the essential oil were identified using GC and GC-MS techniques (Table I and Fig. 1). A total of 25 compounds were identified in the A. capillaris essential oil, accounting for $90.1 \%$ of the total oil composition. The major components of the essential oil were: $\alpha$-pinene $(4.3 \%)$, $\beta$-pinene (12.1\%), limonene (4.5\%), 1,8-cineole (6.2\%), piperitone $(4.2 \%), \beta$-caryophyllene $(5.2 \%)$, capillin $(24.2 \%)$, and germacrene D (3.9\%) (Fig 2). The essential oil of A. capillaris was dominated by the presence of monoterpene hydrocarbons $(29.3 \%)$, oxygenated monoterpenes (18\%), sesquiterpene hydrocarbons (12.4\%), amongst others (24.2\%). Previous studies have also demonstrated that various Artemisia essential oils contain $\alpha$-pinene, $\beta$-pinene, limonene, 1,8 -cineole and capillin as major constituents $(5,18,19)$.

Antibacterial activity. The antibacterial activities of the A. capillaris essential oil, and its major constituents ( $\alpha$-pinene, $\beta$-pinene, limonene, 1,8-cineole, piperitone, $\beta$-caryophyllene and capillin) were evaluated against various clinically significant, and respiratory infection causing, bacterial strains. These included: S. pyogenes, MRSA, MRSA (clinical strain), MGRSA, S. pneumoniae, K. pneumoniae, H. influenzae and $E$. coli. The potency of the essential oil, and its chemical constituents, was assessed by measuring inhibition zones, and MIC and MBC values. The essential oil of A. capillaris and its major constituents exhibited a broad spectrum and variable degree of antibacterial activity against the various tested bacterial strains. The essential oil exhibited potent growth inhibition against $S$. pyogenes $(\mathrm{MIC}=52$ and $\mathrm{MBC}<52$ ), MRSA clinical strain $(\mathrm{MIC}=56, \mathrm{MBC}=98)$, S. pneumoniae $(\mathrm{MIC}=32, \mathrm{MBC}=56)$, K. pneumoniae $(\mathrm{MIC}=32, \mathrm{MBC}=56)$, H. influenzae $(\mathrm{MIC}=26, \mathrm{MBC}=72)$, and $E$. coli $(\mathrm{MIC}=24$, $\mathrm{MBC}=64) \mu \mathrm{g} / \mathrm{ml}$ (Table II). The two bacterial strains MRSA (ATCC 43300) and MGRSA (ATCC 33592) were less susceptible to the effects of the essential oil, and exhibited higher values of MIC and MBC. This reduction in susceptibility may arise from the drug-resistant nature of these bacterial strains.

To identify which of the chemical compounds present in the essential oil of $A$. capillaris, were active against the respiratory bacteria, a further in vitro experiment was conducted to evaluate the antibacterial effects of the major constituents: $\alpha$-pinene, $\beta$-pinene, limonene, 1,8 -cineole, piperitone, $\beta$-caryophyllene and capillin (Table III). Almost all of the tested essential oil constituents exhibited moderate to potent antibacterial effects against the various bacterial strains. However, the essential oil remained much more potent, as compared with the individual chemical constituents. These results indicate there is a possible interplay between the various chemical constituents of the essential oil. Among the chemical compounds, piperitone and capillin exhibited more potent growth inhibition of the bacterial strains. K. pneumoniae, $H$. influenzae and $E$. coli were the most susceptible bacterial strains towards the effects of piperitone and capillin. Piperitone treatment resulted in MIC/MBC values of $86 />86$, $72 />72$ and $72 />72 \mu \mathrm{g} / \mathrm{ml}$ against $K$. pneumoniae, $H$. influenzae and $E$. coli respectively; whereas capillin treatment resulted in MIC/MBC values of 72/>72, 64/>64 and 64/>64 respectively against the above bacterial strains. Among all of the chemical constituents, capillin had the most potent effects against all of the bacterial strains. Capillin was capable of inhibiting the growth of drug resistant bacterial strains, including MRSA 
Table I. Chemical components identified in the essential oil of Artemisia capillaris.

\begin{tabular}{|c|c|c|}
\hline Compound & RI & Relative peak area $(\%)$ \\
\hline Tricyclene & 919 & 2.1 \\
\hline$\alpha$-Thujene & 924 & 1.2 \\
\hline$\alpha$-Pinene & 931 & 4.3 \\
\hline Camphene & 943 & 1.6 \\
\hline$\beta$-Pinene & 981 & 12.1 \\
\hline Limonene & 1021 & 4.5 \\
\hline 1,8-Cineole & 1038 & 0.9 \\
\hline (z)-Ocimene & 1038 & 0.9 \\
\hline Artemesia Ketone & 1045 & 3.5 \\
\hline$\gamma$-Terpinene & 1057 & 2.6 \\
\hline 4-Terpineol & 1179 & 0.7 \\
\hline Citronellol & 1213 & 1.6 \\
\hline Piperitone & 1220 & 4.2 \\
\hline Pulegone & 1224 & 1.8 \\
\hline Eugenol & 1356 & 1.7 \\
\hline$\beta$-Cubebene & 1382 & 0.7 \\
\hline$\beta$-Caryophyllene & 1420 & 5.2 \\
\hline$\beta$-Farnesene & 1438 & 0.9 \\
\hline Capillin & 1457 & 24.2 \\
\hline Germacrene D & 1479 & 3.9 \\
\hline 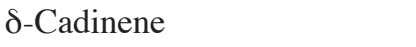 & 1520 & 1.7 \\
\hline Nerolidol & 1564 & 2.0 \\
\hline Spathulenol & 1578 & 2.6 \\
\hline Globulol & 1587 & 0.3 \\
\hline$\alpha$-Cadinol & 1652 & 1.3 \\
\hline Monoterpene Hydrocarbons & & 29.3 \\
\hline Oxygenated Monoterpenes & & 18 \\
\hline Sesquiterpene Hydrocarbons & & 12.4 \\
\hline Oxygenated Sesquiterpenes & & 6.2 \\
\hline Others & & 24.2 \\
\hline Total (\%) & & 90.1 \\
\hline
\end{tabular}

RI, Retention index, calculated using a RTX-5 column.

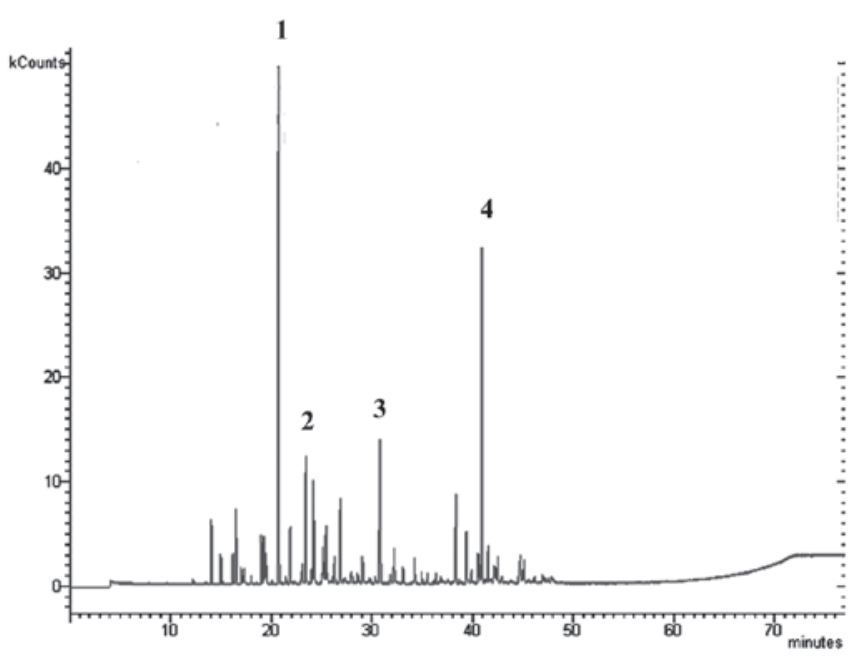

Figure 1. Gas chromatography-mass spectrometry total ion chromatogram of the leaf essential oil of Artemisia capillaris. Numbers represent major components: $1, \beta$-pinene; $2,1,8$-cineole; 3 , $\beta$-carophyllene; 4 , capillin. 

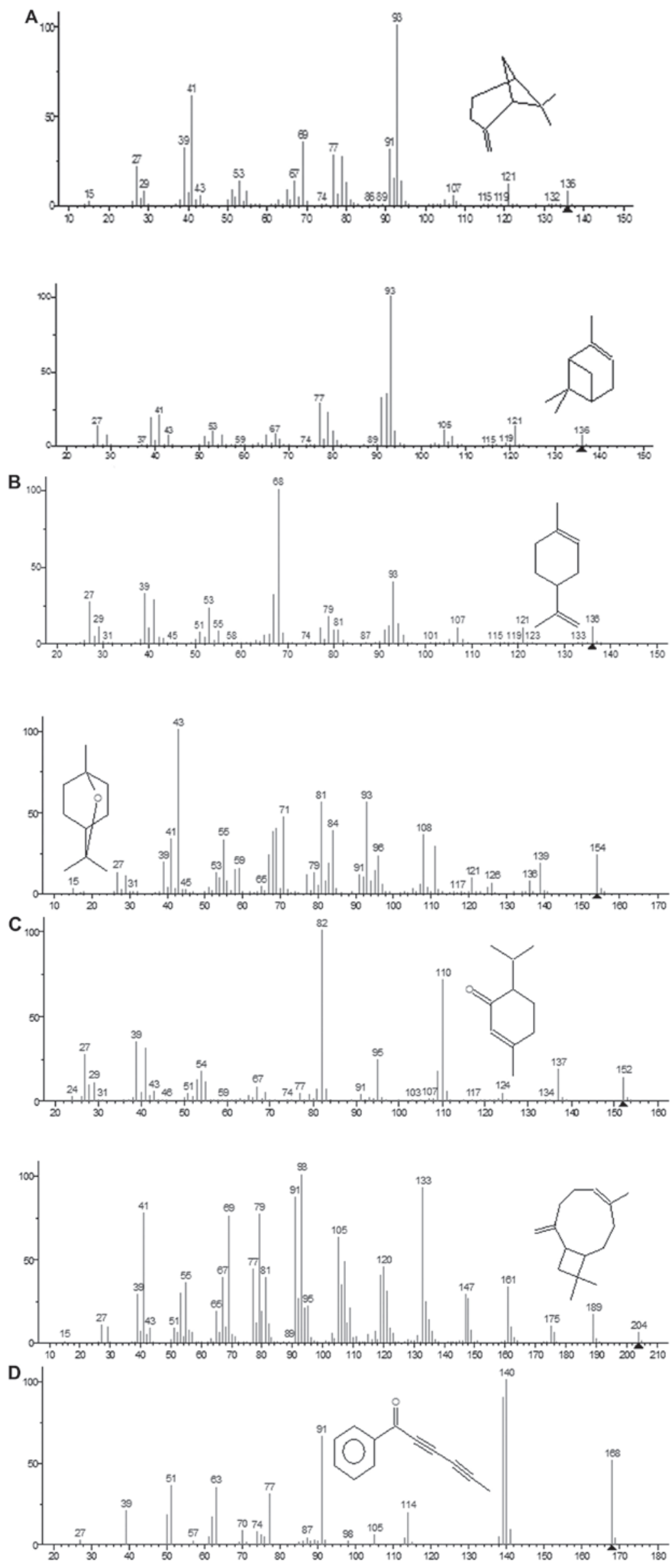

Figure 2. Mass spectra and molecular structures of the major identified compounds present in the essential oil of Artemisia capillaris, (A) $\beta$-Pinene and $\alpha$-Pinene. (B) Limonene and 1,8-Cineole. (C) Piperitone and $\beta$-Caryopyllene. (D) Capillin. 
Table II. Antibacterial activity of the Artemisia capillaris essential oil, minimum inhibitory concentration (MIC) and minimum bacteriocidal concentration (MBC) values.

\begin{tabular}{|c|c|c|c|c|c|c|}
\hline \multirow[b]{2}{*}{ Bacterial strain } & \multicolumn{2}{|c|}{ Essential oil $(\mu \mathrm{g} / \mathrm{ml})$} & \multicolumn{2}{|c|}{ Ampicillin $(\mu \mathrm{g} / \mathrm{ml})$} & \multicolumn{2}{|c|}{ Vancomycin $(\mu \mathrm{g} / \mathrm{ml})$} \\
\hline & MIC & $\mathrm{MBC}$ & MIC & MBC & MIC & $\mathrm{MBC}$ \\
\hline $\begin{array}{l}\text { Streptococcus pyogenes } \\
\text { (ATCC 12344) }\end{array}$ & 52 & $>52$ & 0.7 & $>1.5$ & 0.5 & 1 \\
\hline $\begin{array}{l}\text { MRSA } \\
\text { (ATCC 43300) }\end{array}$ & 72 & 112 & 0.9 & 2 & 0.5 & 1.5 \\
\hline $\begin{array}{l}\text { MRSA } \\
\text { (Clinical strain) }\end{array}$ & 56 & 98 & 0.9 & 2 & 2 & 4 \\
\hline $\begin{array}{l}\text { MGRSA } \\
\text { (ATCC 33592) }\end{array}$ & 98 & $>98$ & 0.5 & 1.2 & 1 & 2 \\
\hline $\begin{array}{l}\text { Streptococcus pneumoniae } \\
\text { (ATCC 2730) }\end{array}$ & 32 & 56 & 2 & 4 & 1 & 2 \\
\hline $\begin{array}{l}\text { Klebsiella pneumoniae } \\
\text { (ATCC 27853) }\end{array}$ & 32 & 56 & 2 & 4 & 2 & 4 \\
\hline $\begin{array}{l}\text { Haemophilus influenzae } \\
\text { (ATCC 33391) }\end{array}$ & 26 & 72 & 1 & 2 & 2 & \\
\hline $\begin{array}{l}\text { Escherichia coli } \\
\text { (Clinical strain) }\end{array}$ & 24 & 64 & 1 & 2 & 1 & 2 \\
\hline
\end{tabular}

MRSA, methicillin-resistant Staphylococcus aureus; MGRSA, methicillin-gentamicin resistant Staphylococcus aureus; ATCC, American Type Culture Collection.
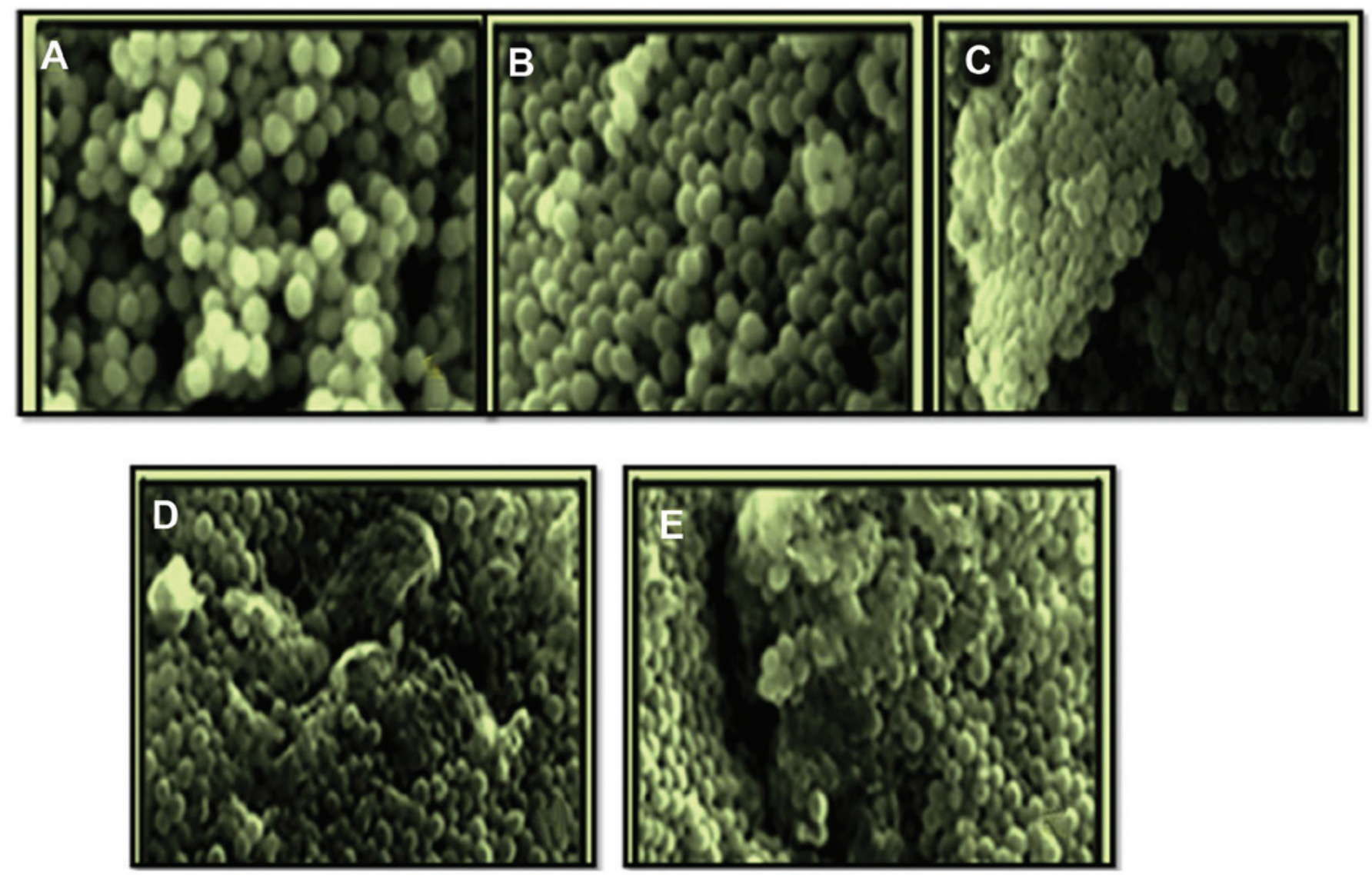

Figure 3. Scanning electron micrographs of Staphylococcus aureus treated with various concentrations of Artemisia capillaris essential oil. (A) S. aureus treated for $12 \mathrm{~h}$ in saline. (B-E) S. aureus treated for $12 \mathrm{~h}$, with $20,40,60$ and $80 \mu \mathrm{g} / \mathrm{ml}$ of the A. capillaris essential oil, respectively. Magnification, x10,000. 


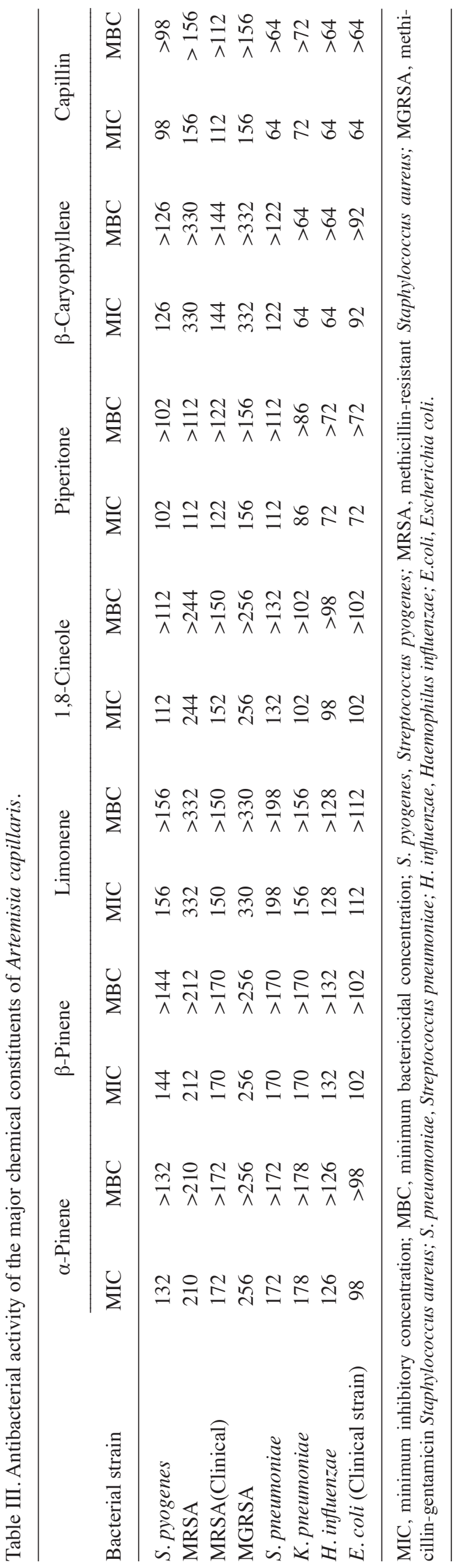
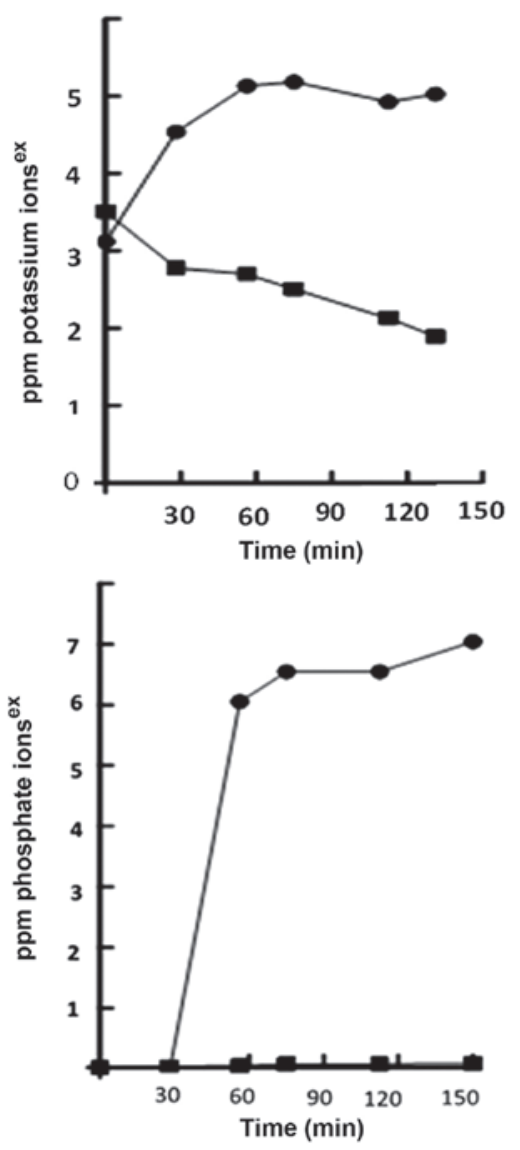

Figure 4. Extracellular concentration of potassium and phosphate ions in aliquots of Staphylococcus aureus untreated (squares) and treated (circles) with $100 \mu \mathrm{l}$ Artemisia capillaris essential oil. The data-points represent the results from two independent experiments (coefficient of variation $<5 \%$ ). Min, minutes; ppm, parts per million; ex, extracellular.

and MGRSA, resulting in MIC/MBC values of 112/>112 and $156 />156$, respectively, against these bacteria.

SEM results. The treatment of $\mathrm{S}$. aureus with $A$. capillaris essential oil, induced marked morphological changes in the bacteria, as determined by SEM. The $S$. aureus bacterial cells were bloated, $12 \mathrm{~h}$ following A. capillaris essential oil treatment $(20,40,60$ and $80 \mu \mathrm{g} / \mathrm{ml})$. The bacterial cells were crushed and collected $48 \mathrm{~h}$ following the treatment with the essential oil of A. capillaris. The essential oil induced cell morphological changes in the $S$. aureus bacterial cells, in a dose-dependent manner, whereas the untreated control cells did not show any changes in cell morphology (Fig. 3). Treatment of S. aureus with $80 \mu \mathrm{g} / \mathrm{ml}$ of the essential oil, for $12 \mathrm{~h}$, killed $>90 \%$ of the bacterial cells. These results indicate that the A. capillaris essential oil produces bactericidal effects against $S$. aureus microbes.

Leakage of phosphate and potassium ions. A $50 \mu \mathrm{g} / \mathrm{ml}$ concentration of A. capillaris essential oil was administered to a culture of $\sim 1 \times 10^{6} \mathrm{cfu} / \mathrm{ml} S$. aureus. The treated bacterial cultures exhibited significant potassium and phosphate ion leakage following essential oil administration, as compared with the untreated controls (Fig. 4). These results indicate that the antimicrobial actions of the essential oil are mediated 
through the leakage of potassium and phosphate ions. It has previously been reported that essential oils may induce the loss of ions which are integral for the sustenance of bacterial strains, and this is known to be one of the predominant mechanisms by which essential oils exhibit their bactericidal effects (20).

\section{Discussion}

Essential oils have been used in traditional medicine for the treatment of bacterial, viral and fungal infections worldwide for centuries (19). Currently, essential oils are used mainly in alternative and holistic medicine, for similar purposes, and may be administered orally, topically or by aromatherapy. An increasing number of studies have recently focussed on elucidating the specific mechanisms of action of essential oils and their components. Emerging evidence has shown that many essential oils have both non-specific and specific mechanisms of action, which vary based on the relative abundance and chemical composition of the components. Elucidation of the mechanism of action of these compounds may enable identification of new antibiotic targets, and exploitation of novel biochemical pathways which are not currently targeted by existing antibiotics. Furthermore, a combination of existing drugs with essential oils and/or their components, may provide an alternative approach to combat emerging drug resistance. Antibiotic resistance is currently outpacing the research and development required to identify new drugs; therefore, scientists are facing a return to the 'pre-antibiotic era'. Essential oils are currently used in the food and beverage industries, and in perfumes and cosmetics. In addition to this, essential oils have been shown to exhibit a broad spectrum of biological activity, which has led to increased interest among scientists. There has been extensive recent research conducted to discover and determine the antimicrobial activity of essential oils (21). The mechanism of action remains unclear, but some studies have suggested that essential oil compounds may penetrate the cell, where they interfere with cellular metabolism (22). Other studies have shown that phenols, such as carvacrol and eugenol, disrupt the cellular membrane and react with the active sites of enzymes. Essential oils and their components may interact with the cell membrane and accumulate in the lipid bilayer of bacteria, occupying a space between the chains of fatty acids $(23,24)$.

It has previously been demonstrated that various Artemisia essential oils, as well as the major components found in A. capillaris essential oil, may possess antimicrobial activities. For example, A. indica (6), A. absinthium (22), A. biennis (22), A. cana (22), A. dracunculus (22), A. frigida (22), A. longifolia (22), A. ludoviciana (22) A. chamaemelifolia (23), A. turcomanica (23), A. annua (24) and A. fragrans (25), which are used in herbal medicines, have been reported to possess antimicrobial properties. Furthermore, the most abundant compounds present in the A. capillaris essential oil: Germacrene D, $\alpha$-pinene, $\beta$-pinene, 1,8-cineole, limonene, have been reported to exhibit antimicrobial activity. $(6,22,24)$. The present study is, to the best of our knowledge, the first to report on the antimicrobial activities of the essential oil of A. capillaris. These results further support the importance of the Artemisia species containing biologically active metabolites for drug development.
In conclusion, the present study has demonstrated that the essential oil of $A$. capillaris produces potent antibacterial effects against various respiratory tract infection-causing microbes. The bactericidal effects of the essential oil are mediated by the induction of significant morphological changes in bacterial cells, as well as promoting the leakage of potassium and phosphate ions from the bacterial cells. The results of the present study are significant, since numerous bacterial strains used have attained drug resistance, and many conventional drugs are not effective against them.

\section{References}

1. Eccles MP, Grimshaw JM, Johnston M, et al: Applying psychological theories to evidence-based clinical practice: identifying factors predictive of managing upper respiratory tract infections without antibiotics. Implement Sci 2: 26, 2007.

2. Mäkelä MJ, Puhakka T, Ruuskanen O, et al: Viruses and bacteria in the etiology of the common cold. J Clin Microbiol 36: 539-542, 1998.

3. Albert RH: Diagnosis and treatment of acute bronchitis. Am Fam Physicianl 82: 1345-1350, 2010.

4. Cohen J and Powderly W: Chapter 33: Bronchitis, Bronchiectasis, and Cystic Fibrosis. In: Infectious Diseases, 2nd edition. Day J (ed). Mosby (Elsevier), Oxford, 2004.

5. Rather MA, Dar BA, Dar MY, et al: Chemical composition, antioxidant and antibacterial activities of the leaf essential oil of Juglans regia L. and its constituents. Phytomedicine 19: 1185-90, 2012.

6. Rashid S, Rather MA, Shah WA and Bhat BA: Chemical composition, antimicrobial, cytotoxic and antioxidant activities of the essential oil of Artemisia indica Willd. Food Chem 138: 693-700, 2013.

7. Bakkali F, Averbeck S, Averbeck D and Idaomar M: Biological effects of essential oils - a review. Food Chem Toxicol 46: 446-475, 2008

8. Edris AE: Pharmaceutical and therapeutic potentials of essential oils and their individual volatile constituents: a review. Phytother Res 21: 308-323, 2007.

9. Rantzsch U, Vacca G, Dück R and Gillissen A: Anti-inflammatory effects of Myrtol standardized and other essential oils on alveolar macrophages from patients with chronic obstructive pulmonary disease. Eur J Med Res 14: 205-9, 2009.

10. Federspil P, Wulkow R and Zimmermann T: Effects of standardized Myrtol in therapy of acute sinusitis - results of a double-blind, randomized multicenter study compared with placebos. Laryngorhinootologie 76: 23-27, 1997 (In German).

11. Schindl R: Inhalational effect of volatile oils. Wien Med Wochenschr 122: 591-593, 1972 (In German).

12. Boyd EM and Sheppard P: Nutmeg oil and camphene as inhaled expectorants. Arch Otolaryngol 92: 372-378, 1970.

13. Burrow A, Eccles R and Jones AS: The effects of camphor, eucalyptus and menthol vapours on nasal resistance to airflow and nasal sensation. Acta Otolaryngol 96:157-161, 1983.

14. Shubina LP, Siurin SA and Savchenko VM: Inhalations of essential oils in the combined treatment of patients with chronic bronchitis. Vrach Delo 5: 66-67, 1990 (In Russian).

15. Fröhlich E: Lavender oil, review of clinical, pharmacological and bacteriological studies. Contribution to classification of the mechanism of action. Wien Med Wochenschr 118: 345-350, 1968 (In German).

16. Europarådet, European Pharmacopoeia Commission: European Pharmacopoeia. Vol 3. Maisonneuve SA, Sainte-Ruffine, pp 68-71, 1975.

17. Adams RP: Identification of essential oil components by gas chromatography/mass spectrometry. Stream C (ed). Allured Publishing Corporation, Illinois, USA, 2007.

18. Ashour ML, El-Readi M, Youns M, et al: Chemical composition and biological activity of the essential oil obtained from Bupleurum marginatum (Apiaceae). JPharm Pharmacol 61:10791087, 2009.

19. Ríos JL and Recio MC: Medicinal plants and antimicrobial activity. J Ethnopharmacol 22: 80-84, 2005.

20. Cox SD, Gustafson JE, Mann CM, Markham JL, Liew YC, Hartland RP, Bell HC, Warmington JR and Wyllie SG: Tea tree oil causes $\mathrm{K}+$ leakage and inhibits re spirationin Escherichia coli. Lett Appl Microbiol 26: 355-358, 1998. 
21. Saad Y, Muller D and Lobstein A: Major bioactivities and mechanism of action of essential oils and their components. Flavour Fragrance J 28, 269-279, 2013.

22. Kalemba D and Kunicka A: Antibacterial and antifungal properties of essential oils. Curr Med Chem 10: 813-829, 2003.

23. Dorman HJ and Deans SG: Antimicrobial agents from plants: antibacterial activity of plant volatile oils. J Appl Microbiol 88: 308-316, 2000
24. Adorjan B and Buchbauer G: Biological properties of essential oils: an updated review. Flavour Fragr J 25: 407-426, 2010.

25. Lopes-Lutz D, Alviano DS, Alviano CS and Kolodziejczyk PP. Screening of chemical composition, antimicrobial and antioxidant activities of Artemisia essential oils. Phytochemistry 69: 1732-1738, 2008. 